\title{
Damage and regeneration: links to growth in the reef-building coral Montastrea annularis
}

\author{
Erik H. Meesters ${ }^{1}$, Marco Noordeloos ${ }^{1}$, Rolf P. M. Bak ${ }^{1,2}$ \\ ${ }^{1}$ Institute of Taxonomic Zoology, PO Box 4766, 1009 AT Amsterdam, The Netherlands \\ ${ }^{2}$ Netherlands Institute for Sea Research (NIOZ), PO Box 59, 1790 AB Den Burg, The Netherlands
}

\begin{abstract}
The influence of colony tissue regeneration on growth was studied in the reef-building coral Montastrea annularis (Ellis \& Solander, 1786) by buoyant weighing. Experimental corals consisted of a series of cores, 2 cores from each of 20 colonies. One core of each pair was artificially damaged by removing approximately $1 \mathrm{~cm}^{2}$ of tissue and skeleton, the other served as a control for normal growth. Growth was measured as calcification, i.e. mg calcium carbonate production. There was a linear relation between growth and solar radiation. Variation in growth, calculated before the regeneration experiment, was insignificant between cores from the same colony but significantly different between colonies. Growth was reduced in damaged cores when compared to controls. Calcification decreased immediately upon damage and remained reduced during the whole study ( $56 \mathrm{~d}$ ). Lesions caused by physical damage did not always close completely. We propose and test a model that describes regeneration in terms of closure of lesions. This model includes an asymptote in an exponentially decreasing function. Calcification remained suppressed after regeneration slowed down and lesions were still not completely closed, probably because of the formation of polyps and skeletal features in the new tissue. We suggest regeneration to be fuelled by polyps and tissue directly bordering the damaged area. Also, successful regeneration depends on the amount of tissue bordering a lesion and not on colony size.
\end{abstract}

KEY WORDS: Coral · Damage · Regeneration · Growth · Lesion · Energy · Scleractinia

\section{INTRODUCTION}

Reefs throughout the world are degrading through anthropogenic disturbances (Colloquium and Forum on Global Aspects of Coral Reefs, Miami, FL, USA, 1993). The most imminent anthropogenic threats to coral reefs are nutrient enrichment and increased sedimentation (e.g. Tomascik \& Sander 1985, 1987a, b, Rogers 1990, Tomascik 1990, 1991, Babcock \& Davies 1991, Hunte \& Wittenberg 1992, Wittenberg \& Hunte 1992). Human disturbances may act synergistically with other disturbances (human or nonhuman) and irreversibly increase damage and mortality on coral reefs. Hermatypic corals, the main actors in the construction and maintenance of coral reefs, suffer damage from hurricanes (Rogers 1993), sedimentation (Bak \& Elgershuizen 1976, Bak 1978), temperature (Jokiel \& Coles 1990), emersion at low tide (Loya 1972, Babcock 1991), predation (Ott \& Lewis 1972, Endean 1973, Bak
\& Eys 1975, Cameron et al. 1991), competition (Lang \& Chornesky 1990), and man (Brown \& Howard 1985).

Polyps are the modules building the coral colony, which has clonal characteristics (Jackson \& Coates 1986). Mortality of polyps will result in partial mortality of coral colony surfaces. Such lesions, patches of bare skeleton, are (wholly or partly) surrounded by the remaining living colony surface tissue. Lesions can become a permanent feature, colonised by competing organisms (e.g. algae, excavating sponges), but often a colony will restore its former integrity through the regeneration of tissue and skeleton (Loya 1976, Bak et al. 1977, Bak \& Steward-van Es 1980, Bak 1983, Meesters et al. 1992, Meesters \& Bak 1993).

Regeneration plays a fundamental role in colony survival. Because it requires energy, regeneration affects growth (Bak 1983), reproduction (Rinkevich \& Loya 1989), and possibly also resistance to diseases (Bak \& Criens 1981), as well as competitive ability. The regen- 
eration of a wound starts by the formation of a new tissue layer that is formed by the surrounding tissue. Polyps and new septa start to emerge in this layer after approximately $2 \mathrm{wk}$. In fast regenerating species (e.g. Acropora palmata and Meandrina meandrites) this means that lesions may be completely closed by new tissue before any sign of new polyps appears in the new tissue. In general, the regeneration of a lesion, expressed in terms of a reduction in lesion size, follows an exponentially decreasing curve (Bak 1983, Meesters et al. 1992, Meesters \& Bak 1993). However, environmental stress, lesion size, and competition can prevent lesion closure (Bak et al. 1977, Bak \& Stewardvan Es 1980, Meesters et al. 1992, Meesters \& Bak 1993). In such cases lesion size may never approach zero (although the exponential regression line does). When the regeneration rate is lower, lesions remain open longer. This means increased possibility of successful settlement of alien organisms in this new patch of bare skeleton. Subsequent competition between coral and settler may result in coral damage and mortality.

Growth rates of corals have often been used as a measure of environmental stress (e.g. Dodge et al. 1974, Bak 1978, Hudson 1981, Neudecker 1981, Kendall et al. 1983, Cortes \& Risk 1985). Damage to a coral means metabolic stress, because the regeneration of damage implies loss of energy. Bak (1983) found reduced growth (measured as skeletal extension) in Acropora palmata 2 mo after lesion infliction. Methods for measuring growth often have the disadvantage of either requiring long time intervals to measure a substantial growth increment or to require the coral to be

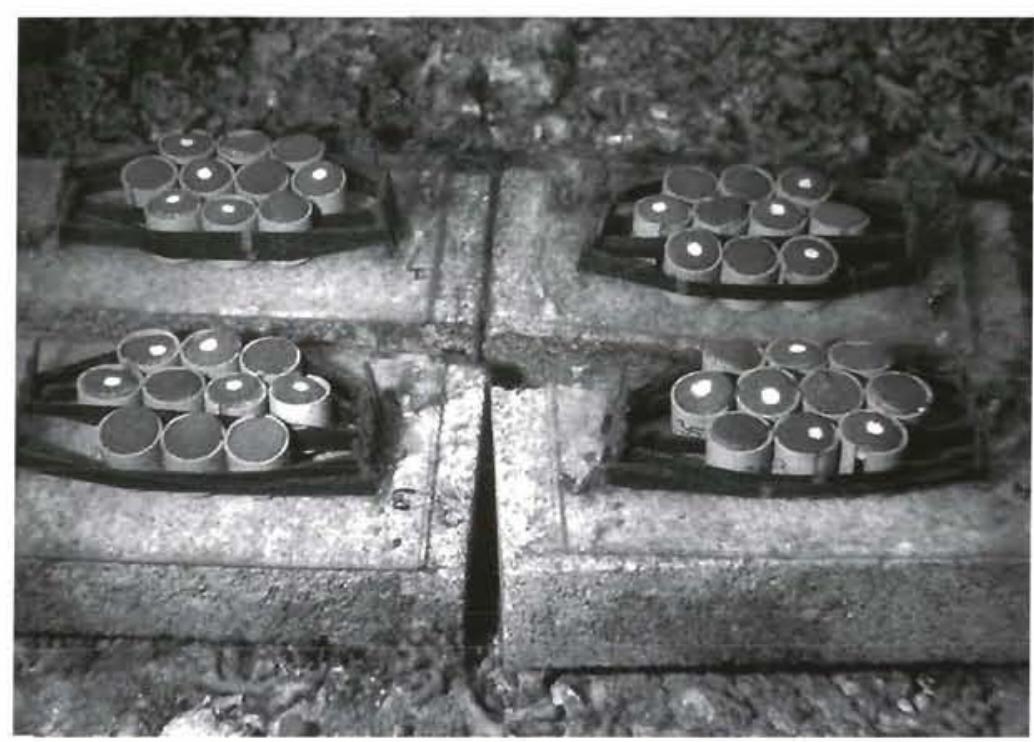

Fig. 1. Montastrea annularis. Experimental cores in situ sacrificed. Dodge et al. (1984) and Davies (1989) modified the method of buoyant weighing (Franzisket 1964, Bak 1973), which is non-destructive, to provide shortterm measurements of coral growth. In this paper we report the influence of the regeneration of small lesions on the short-term growth of the coral Montastrea annularis (Ellis \& Solander, 1786) using the method of Davies (1989). We propose a model that accurately describes complete and incomplete regeneration.

\section{MATERIALS AND METHODS}

We studied the effects of lesion regeneration on the growth of the coral Montastrea annularis, the main reef-building coral in the Caribbean, at the island of Curaçao, Netherlands Antilles. The experiments were restricted to the columnar morphotype (Van Veghel \& Bak 1993), which is the most common type on the reefs of Curaçao. Two cores (diameter $3.7 \mathrm{~cm}$ ) were sawcut from each of 20 haphazardly collected colonies. In this way 2 samples of the same genetic identity were obtained that enabled determination of intra-colony growth variation and that, more importantly, made the regeneration experiment a pairwise design, excluding variation between colonies. The cores were clamped into pre-weighed tight-fitting PVC tubes and returned to the collecting site (Carmabi buoy 1, depth $7 \mathrm{~m}$; Fig. 1). They were left undisturbed on the reef while the tissue on the edge of the cores regenerated. After $3 \mathrm{wk}$ all core edge damage had been regenerated and the cores were ready for the experiments.

Growth. Growth of the cores was determined by buoyant weighing (Franzisket 1964, Bak 1973, 1976, Jokiel et al. 1978, Dodge et al. 1984), recently modified by Davies (1989) to increase accuracy. We applied this modified method using a Sartorius 1217 MP electronic balance. To weigh the cores they were retrieved from the reef, quickly transported to the laboratory, and returned within 2 to $6 \mathrm{~h}$. The cores were kept underwater and heavily shaded during the whole process. Practically, they received light only when in situ on the reef. Mean density of PVC was determined by weighing 10 pieces of PVC in air and water with known density. Calcium carbonate density was calculated by weighing 10 small cores in water with known density and in air after drying to constant weight. 
Three factors potentially influence growth in our experiments: light, handling, and regeneration. To separate them we first assessed the effects of light and handling.

Light. Coral calcification is closely linked to photosynthesis (Kawaguti \& Sukamoto 1948, Goreau 1963), and is therefore light-enhanced (Goreau 1959). Calcification and photosynthesis can be described by the same light-dependent model (Bosscher \& Meesters 1992). Total integrated irradiance during an overcast day may be less than $50 \%$ of a normal sunny day and this can influence growth (Davies 1991).

In our experiments cores could not be weighed at exactly the same time each measuring day. Consequently they received different amounts of light. Therefore, and to correct for daily variations in irradiance, we standardised growth to the average integrated daily radiation. Standardisation was done by dividing growth by total irradiance integrated over the time the core was at the experimental site and multiplying that by the amount of light of a normal day. We tested the assumption of a linear relation between growth and light. Hourly radiation measurements were obtained from the Curaçao Meteorological Survey at Hato Airport. During our study total integrated irradiance of an average day was approximately $49.8 \mathrm{E}$ $\mathrm{m}^{-2}$ of photosynthetically active radiation (PAR; 400 to $700 \mathrm{~nm}$ wavelength). This equals approximately $3000 \mathrm{Wh} \mathrm{m}^{-2}$.

Handling. To assess the influence of handling, including repeated transport to the laboratory and repeated weighing, a nested design was used. The 20 colonies ( 2 cores colony $^{-1}$ ) were randomly assigned to 3 groups that were weighed at different intervals during a $16 \mathrm{~d}$ period. Cores of the first group were measured at the end of every second day; cores of the second and third group were measured at the end of every fourth and eighth day respectively. After $16 \mathrm{~d}$ the total increase in weight was determined for each core. Because cores of the first group had been handled, respectively, 2 and 4 times as often as the second and third group (and the second group twice as often as the third group), thus receiving less light, growth of each core was standardised to average accumulated daily radiation.

Regeneration and growth. To study regeneration, a lesion was made on one of the 2 cores from each colony with a cylindrical grinding stone $(\varnothing 10 \mathrm{~mm})$. The average lesion surface area (including the shallow wall of the lesion) and depth were respectively $170 \mathrm{~mm}^{2}$ (SE = $6.6)$ and $2.16 \mathrm{~mm}(0.19, \mathrm{n}=20)$. The initial area of living tissue that was removed with lesion infliction was subtracted from the total core area when growth was calculated per $\mathrm{cm}^{2}$. This makes our growth estimates conservative in that the difference in growth between cores with and without a lesion could only be more and not less.

Lesion recovery was followed through time in terms of lesion size. Simple exponential regression (Lesion size $=S_{0} \times 10^{\text {(slope } \times \text { days) }}$ has been used effectively to describe lesion regeneration (Bak 1983, Meesters \& Bak 1993). This model assumes that lesion size will eventually approach zero. However, lesions are sometimes not completely closed. Initially intrinsic, later extrinsic factors such as settlement of organisms in the lesions can be responsible. Consequently, regeneration may be better described by the model: Lesion size $=S_{\infty}+\left(S_{\max } \times 10^{\text {(slope } \times \text { daysi }}\right)$, which is a modification of the equations of Bertalanffy (1957). This model simply states that lesion size decreases exponentially to an asymptote $\left(S_{\infty}\right)$ determined by the initial lesion size, which is the sum of the asymptotic value $\left(S_{\infty}\right)$ and the maximum lesion size that will be closed completely $\left(S_{\max }\right)$. The slope and $S_{\max }$ depend on the regeneration potential of the species and environmental conditions. $S_{\infty}$ depends on species and initial lesion size. As regeneration rate decreases, alien organisms become more firmly established in the lesion and lesion size approaches $S_{\infty}$.

Statistics. The influence of handling (every 2, 4 or 8 d) was tested with a nested ANOVA (Sokal \& Rohlf 1981, Zar 1984). The model describing lesion regeneration was calculated by an iterative line fitting method using least squares (the 'Simplex estimation method'). To calculate the standard error of the mean lesion size at each data point, the mean square error (MSE) of a repeated-measures ANOVA was used. The assumption of no interaction between time and lesions in this analysis is valid because all lesions displayed the same regeneration pattern. The effect of lesion regeneration on growth was tested by a repeated-measures ANOVA (the same cores were measured through time). Since the statistical design is basically a repeated-measures ANOVA with paired data, we simplified the analysis by taking the difference in growth between the cores from the same colony (one with, and one without a lesion) as dependent variable. A priori planned comparisons were between growth difference before lesion infliction, after, and the interaction between before and after. The assumption of no interaction between time and colonies was justified by a pilot study with replicated data, which revealed no significant interaction between these factors $\left(\mathrm{F}_{27,40}=1.25, \mathrm{n}=80\right.$, $p=0.26$ ). Furthermore, a correction of the MSE was calculated with Tuckey's test for non-additivity (Sokal \& Rohlf 1981). ANOVA assumptions of all analyses were graphically checked. Standard errors and confidence limits in figures were calculated from the MSE in the statistical tests. All analyses were performed with the program Systat (Wilkinson 1989). 


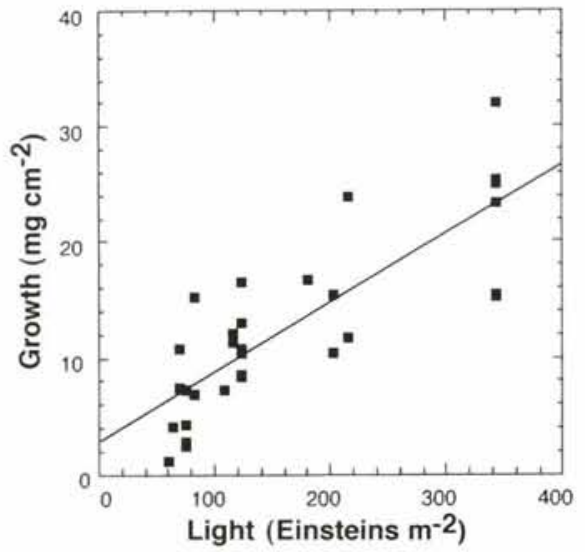

Fig. 2. Montastrea annularis. Mean growth of randomly selected growth measurements $(\mathrm{n}=30)$ in our data set, related to received radiation. Regression: Growth $=2.58+(0.06 \times$ Light); $\mathrm{r}^{2}=0.67 ; \mathrm{p}<0.001$

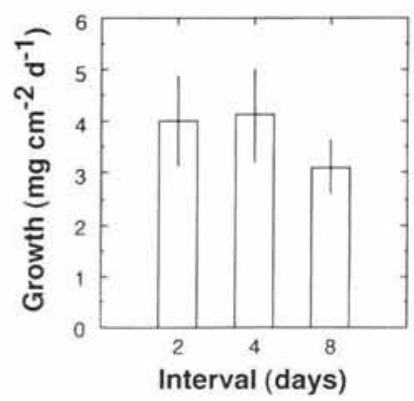

Fig. 3. Montastrea annularis. Mean colony growth after $16 \mathrm{~d}$ of series of colonies measured every 2, 4, and $8 \mathrm{~d}$. Vertical lines denote $95 \%$ confidence limits. Number of samples per group: $\mathrm{n}_{2}=10 ; \mathrm{n}_{4}=10 ; \mathrm{n}_{8}=20$

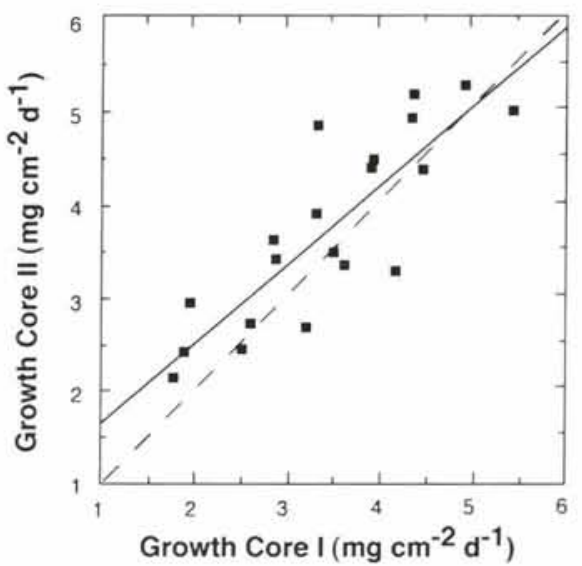

Fig. 4. Montastrea annularis. Similarity in growth between the 2 cores (Core I and Core II) of each colony $(n=20)$, after 18 d. Dashed line represents equal growth. Solid line is regression line; Growth core $\mathrm{II}=0.85+(0.83 \times$ Growth core I);

$$
r^{2}=0.71, p<0.001
$$

\section{RESULTS}

Light

There is a linear relationship between growth, measured as weight increase, and the amount of irradiance a core had received since the previous weighing (Fig. 2). Because average daily irradiance was about $49.8 \mathrm{E} \mathrm{m}^{-2}$, data points in the figure represent approximately 1, 2, 4 and $7 \mathrm{~d}$ of light. The variation between colonies is of the same magnitude whether corals were weighed after 1,2, 4 or $7 \mathrm{~d}$. Calcification increases by $1 \mathrm{mg} \mathrm{cm}^{-2}$ every additional $16 \mathrm{E} \mathrm{m}^{-2}$ (PAR) and on an average day weight increases about $3 \mathrm{mg} \mathrm{cm}^{-2}$.

\section{Handling}

Handling included collecting, transporting to the laboratory, weighing and taking the corals back to the reef. Mean growth of 3 groups of colonies ( 2 cores per colony) handled 2, 4 or 8 times in $16 \mathrm{~d}$ is shown in Fig. 3.

If there had been a handling effect, one would expect growth to be higher when a colony is handled less. Instead, mean growth for colonies sampled only once every $8 \mathrm{~d}$ was even less than for colonies in the other 2 treatments. However, there was no significant difference in growth between the 3 handling intensities (Table 1). The overall mean growth was $3.60 \mathrm{mg}$ $\mathrm{cm}^{-2} \mathrm{~d}^{-1}(\mathrm{SE}=0.20$; range 1.78 to 5.45$)$.

Table 1 shows a large added variance component among colonies within each treatment $(\mathrm{p}<0.001)$. This is caused by large differences in growth between colonies (Fig. 4). The coefficient of variation, i.e. the standard deviation expressed as a percentage of the mean, a measure that is independent of the unit of measurement, was $27.3 \%$ for colony growth. The MSE of Table 1, estimating the average variance between the 2 cores of each colony, is very small. Cores from the same colony grow approximately equally fast, but mean growth between colonies may differ by a factor

Table 1. Montastrea annularis. Nested ANOVA on mean daily growth of colonies sampled every 2,4 , and $8 \mathrm{~d}$ at the end of a $16 \mathrm{~d}$ period. Colonies are nested within the 3 treatments. $\cdots p<0.001$

\begin{tabular}{lrrrl}
\hline Source of variation & \multicolumn{1}{c}{ SS } & df & MS & $F$ \\
\hline Interval & 9.16 & 2 & 4.578 & 2.93 \\
Colony $\times$ Interval & 26.60 & 17 & 1.565 & $8.34 \cdots$ \\
Error & 3.75 & 20 & 0.188 & \\
Total & 39.51 & 39 & & \\
& & & & \\
\hline
\end{tabular}


of 2.5. This is illustrated in Fig. 4 by the spread of the points along the regression line, which approximates variation between colonies, and the average smallest distance of the data points to the regression line, which is approximately equal to the variation between cores.

Growth (standardised to an average day of $49.8 \mathrm{E}$ $\mathrm{m}^{-2}$, PAR) was not significantly different between cores from the same colony. A regression analysis of the data in Fig. 4 gives a slope of $0.83( \pm 0.27,95 \%$ CL) with a coefficient of determination $\left(\mathrm{r}^{2}\right)$ of 0.71 . This slope is not significantly different from 1 ( $t$-test, $t=$ $1.36, \mathrm{df}=18, \mathrm{p}>0.1)$, meaning that there is no difference between cores from the same colony.

\section{Regeneration and growth}

After lesions were made, the surrounding tissue started to recover the bare skeleton at a fast rate (Fig. 5). Mean lesion size decreased with time (repeated-measures ANOVA, $\mathrm{p}<0.001$ ), but no lesion was closed during this study and mean lesion size reached an asymptote at approximately $35 \mathrm{~mm}^{2}$.

The theoretical model [Lesion size $=S_{\infty}+\left(S_{\max } \times\right.$ $10^{\text {(slope } \times \text { days) })}$ ], which included an asymptote, proved a good approximation for the regeneration process (Table 2). The line that is estimated by the model is shown in Fig. $5\left(r^{2}=0.73\right)$. Lesions with an average size of $170 \mathrm{~mm}^{2}$ regenerated only to a size of $35 \mathrm{~mm}^{2}\left(S_{\infty}\right)$; the maximal closable lesion size $\left(S_{\max }\right)$ is $130 \mathrm{~mm}^{2}$. An alternative model, which uses an exponential regression and assumes no asymptote $($ Size $=$ Constant $\times$ $\left.10^{\text {(slope } \times \text { days) }}\right)$, accounted for only $53 \%$ of the total variation.

Mean growth of undamaged cores and regenerating cores is shown in Fig. 6. Before lesion infliction the average growth of the 2 groups of cores was 3.65 and $3.39 \mathrm{mg} \mathrm{cm}^{-2} \mathrm{~d}^{-1}(\mathrm{SE}=0.10)$. During the period after infliction of lesions there was a large difference in growth between damaged and undamaged cores. The average growth during this period was $1.49 \mathrm{mg} \mathrm{cm}^{-2}$ $\mathrm{d}^{-1}$ for damaged cores and $2.19(\mathrm{SE}=0.05)$ for undam-

Table 2. Estimated parameters $( \pm S E)$ in the model: Lesion size $=S_{\infty}+\left(S_{\max } \times 10^{\text {(slope } \times \text { days) }}\right)$. The parameters were estimated by an iterative line fitting model using least squares. $S_{\infty}$ : the size to which an average lesion (of size $S_{\infty}+S_{\max }$ ) in Montastrea annularis will be healed; $S_{\max }$ : the maximum lesion size that will completely regenerate; Slope: the slope of the regression line; $\mathrm{n}=240$

\begin{tabular}{|lrrrr|}
\hline & $S_{\infty}$ & $S_{\max }$ & Slope & $\mathrm{r}^{2}$ \\
\hline Mean & 35.02 & 130.27 & -0.050 & 0.73 \\
SE & 3.14 & 5.19 & 0.005 & \\
\hline
\end{tabular}

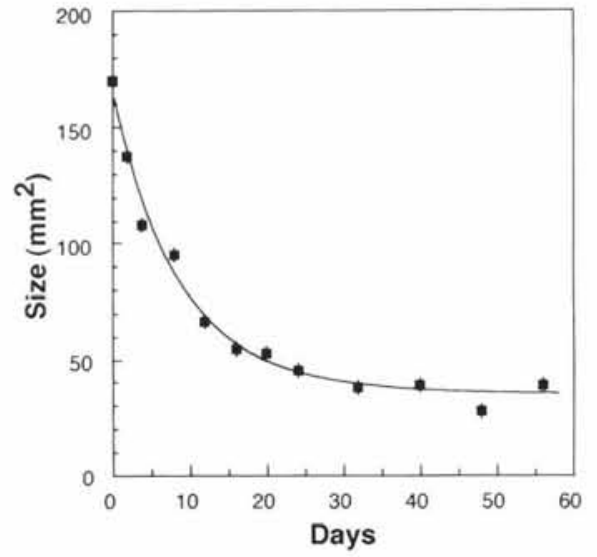

Fig. 5. Montastrea annularis. Mean lesion size ( \pm SE) at infliction of lesion and subsequently through time. The model, Size $=S_{\infty}+\left(S_{\max } \times 10^{\text {(slope } \times \text { days })}\right)$, results in the line Size $=35+$ $\left(130 \times 10^{(-0.05 \times \text { days })}\right), \mathrm{r}^{2}=0.73, \mathrm{n}=240$. For abbreviations in the model see text

aged cores. Growth remained suppressed in the regenerating cores even after lesion tissue regeneration (Fig. 5) stopped after approximately $30 \mathrm{~d}$.

There was no significant difference in growth of all cores at both dates before lesion infliction (Fig. 7, Table 3). After lesion infliction there is also no difference between days (factor 'After' in Table 3). However, during this period there is a large difference in growth between undamaged and regenerating cores (significant interaction term in Table 3). Mean growth differences $\left(\mathrm{mg} \mathrm{cm}^{-2} \mathrm{~d}^{-1} \pm 95 \% \mathrm{CL}\right.$ ) for the period before and after are respectively $0.26( \pm 0.28)$ and 0.70 $( \pm 0.13)$. Before lesion infliction the difference in growth was not different from zero, while after lesion infliction the difference between cores with and without a lesion was negative, which means that cores without a lesion were growing faster.

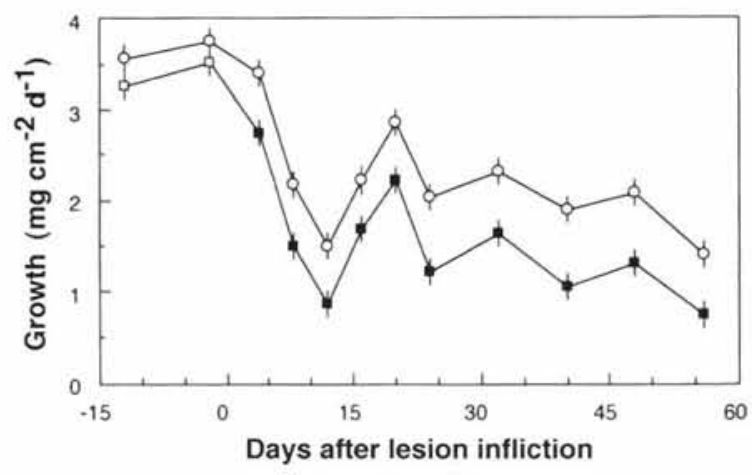

Fig. 6. Montastrea annularis. Mean growth $( \pm \mathrm{SE})$ of cores from 20 colonies $\left(2\right.$ cores colony $\left.{ }^{-1}\right)$ relative to the time of lesion infliction. One core of each colony received a lesion ( $\mathbf{m})$, while the other served as a control $(\square, 0)$. Cores before Day 0 have no lesion 


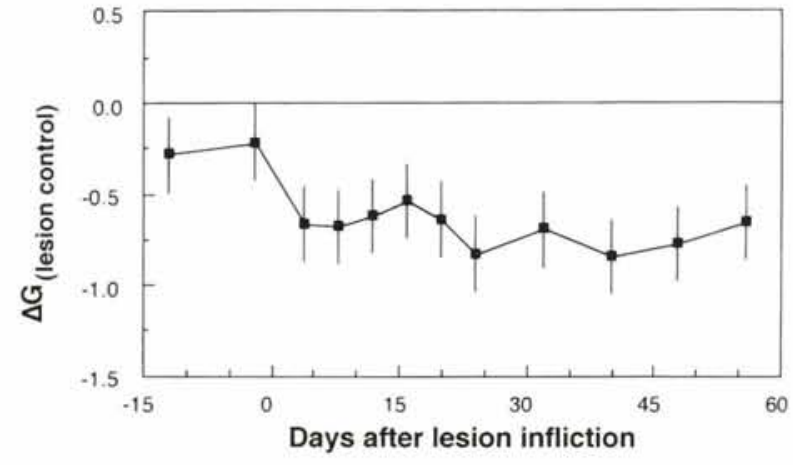

Fig. 7. Montastrea annularis. Mean difference in growth ( $\mathrm{mg} \mathrm{cm} \mathrm{cm}^{-2} \mathrm{~d}^{-1}, \pm \mathrm{SE}$ ) between damaged and undamaged cores relative to the time of lesion infliction. Horizontal line represent equal growth

Growth of both groups, i.e. undamaged cores and regenerating cores, appeared to be decreasing through time (Fig. 6). This was affirmed by an ANOVA on the growth data of the cores without a lesion (Table 4). The same analysis of the growth data of the

Table 3. Montastrea annularis. Repeated-measures ANOVA on the difference in growth between cores with and without a lesion through time. Time is partitioned into measurements before lesions were made, measurements after lesions were made, and an interaction between before and after. ${ }^{\circ} \mathrm{p}<0.05$; $\because p<0.01$

\begin{tabular}{|lrrll|}
\hline Source of variation & \multicolumn{1}{c}{ SS } & df & MS & $F$ \\
\hline Colony & 95.60 & 19 & 5.03 & $6.22 \cdots$ \\
Time & 7.82 & 11 & 0.71 & 0.88 \\
$\quad$ Before & 0.07 & 1 & 0.10 & 0.12 \\
$\quad$ After & 1.63 & 9 & 0.18 & 0.22 \\
$\quad$ Before $\times$ After & 6.12 & 1 & 6.12 & $7.57^{\cdots}$ \\
Error & 170.76 & 209 & 0.82 & \\
$\quad$ Non-additivity & 3.30 & 1 & 3.30 & $4.08^{*}$ \\
$\quad$ Error & 168.10 & 208 & 0.81 & \\
Total & 282.69 & 239 & & \\
\hline
\end{tabular}

Table 4. Montastrea annularis. Repeated-measures ANOVA and regression of the growth of the cores without a lesion through time $(\mathrm{n}=240)$. Resulting linear regression equation: Growth $=3.36-(0.03 \times$ Time $) ; r^{2}=0.20 .{ }_{p}<0.01 ; \cdots p<0.001$

\begin{tabular}{|lrrrr|}
\hline Source of variation & SS & df & MS & \multicolumn{1}{c|}{$F$} \\
\hline Cores & 113.16 & 19 & 5.96 & $9.87 \cdots$ \\
$\quad$ Time & 137.06 & 11 & 12.46 & $20.64 \cdots$ \\
$\quad$ Regression & 74.26 & 1 & 74.26 & $11.87 \cdots$ \\
$\quad$ Deviations & 62.79 & 10 & 6.28 & $10.40 \cdots$ \\
Error & 126.16 & 209 & 0.60 & \\
Total & 376.38 & 239 & & \\
\hline
\end{tabular}

damaged cores also showed a decrease in growth during time, although this might have been affected by regeneration $\left(F_{19.11}=29.04, \mathrm{p}<0.001\right)$.

\section{DISCUSSION}

\section{Regeneration and growth}

The results clearly demonstrate that growth decreases in Montastrea annularis after lesion infliction (Figs. $6 \& 7$, Table 3 ). A lesion of only $8.8 \%$ of the total tissue area of the core suppressed growth by approximately $32 \%$ during a period of at least $56 \mathrm{~d}$. Growth remained suppressed even after regeneration, in terms of lesion tissue recovery, stopped (Figs. 5 \& 7). The formation of septa, polyps and internal structures that emerge when tissue regeneration slows down is probably responsible for the prolonged reduction of growth. A similar prolonged impact of damage has been recorded as a decrease in skeletal extension over an extended period of time (Bak \& Criens 1981, Bak 1983 ) and a decrease in reproductive output (Rinkevich \& Loya 1989, Meesters unpubl.).

Damage is a serious intervention in coral colony processes. Corals respond by diverting a considerable amount of available energy to regeneration and this reduces growth. Regeneration of damage in corals differs between species and is affected by sedimentation, bleaching, kind of damage and surface area of the lesion (Bak et al. 1977, Bak \& Steward-van Es 1980, Bak \& Criens 1981, Bak 1983, Lester \& Bak 1985, Meesters et al. 1992, Meesters \& Bak 1993).

An intrinsic characteristic of the regeneration process appears to be the exponential decrease in lesion size (Bak 1983, Meesters et al. 1992). But this decrease in size often ceases before lesions are completely closed; a simple exponential regression, as it will always approach zero, will not provide the best description of the process. With the introduction of an asymptote in the exponential regression, regeneration and cessation of regeneration is much better described (Fig. 5).

We do not know why regeneration stops before a wound is fully closed. During the first week after lesion infliction the only organisms that settle in lesions are filamentous algae. They do not appear to slow down regeneration. Corals are known to overgrow algae that have infested dead parts of colonies (Fishelson 1973, Bak et al. 1977).

Lesion size is important in regeneration, because lesions above a certain size will not be recovered by new tissue and will be colonised by other organisms. But even in large lesions there will be an initial phase of regeneration, an effort of the coral to close the 
lesion. It is remarkable that regeneration of larger lesions stops after approximately the same time as in smaller lesions (Bak et al. 1977, Bak \& Steward-van Es 1980, Meesters unpubl.). This indicates that regeneration is primarily fuelled by a definite and limited source, presumably by the polyps and tissue directly bordering the lesion. Regeneration per lesion perimeter length should then be the same in small and large lesions. Regenerative effort, the total amount of tissue regenerated per initial lesion perimeter length, was approximately the same $\left(2.5\right.$ and $\left.2.25 \mathrm{~mm}^{2} \mathrm{~mm}^{-1}\right)$ for large $\left(5 \mathrm{~cm}^{2}\right)$ and small $\left(1 \mathrm{~cm}^{2}\right)$ lesions in Porites astreoides (Bak \& Steward-van Es 1980).

This means that an influence of colony size on regeneration is only expected in very small colonies, where the perimeter of a lesion includes all supportive tissue. Loya (1976) found survival in regenerating colonies of Stylophora pistillata smaller than $1.5 \mathrm{~cm}$ (average radius) to be low when compared to larger colonies. These small colonies were probably below a threshold size. No such relation was found in colonies ranging from 150 to $1100 \mathrm{~cm}^{2}$ (Bak \& Steward-van Es 1990).

If we assume that growth rates are normal in the larger part of the core surface but zero in an area along the perimeter of the lesion, we can calculate the size of the affected area. The average growth rate of a damaged core was $1.49 \mathrm{mg} \mathrm{cm}^{-2} \mathrm{~d}^{-1}$. Its total tissue surface area was approximately $9.75 \mathrm{~cm}^{2}$ [i.e. 10.75 minus the (projected) lesion area of $1 \mathrm{~cm}^{2}$ ]. A damaged core would therefore calcify $14.5 \mathrm{mg} \mathrm{d}^{-1}$. This can be accounted for by $6.6 \mathrm{~cm}^{2}$ of tissue from an undamaged core (mean growth of an undamaged core was $2.19 \mathrm{mg}$ $\mathrm{cm}^{-2} \mathrm{~d}^{-1}$. Because the core is circular, we assume that the area of normally growing tissue is situated in a ring from the outer edge inwardly. Subtracting the $6.6 \mathrm{~cm}^{2}$ from the total core area of $10.75 \mathrm{~cm}^{2}$ results in a total area, including the lesion, with a radius of $11.5 \mathrm{~mm}$. This means that the affected area stretches only $6 \mathrm{~mm}$ from the edge of the lesion, approximately the width of 2 polyps.

The loss of energy to regeneration may thus depend on the length of lesion perimeter, and not on lesion size or colony size. If the lesion perimeter / lesion surface-area ratio is high, the lesion will be closed and the regeneration process may not use the potentially maximal amount of energy that can be allocated to regeneration. If on the other hand this ratio is low, regeneration will use all available energy and a lesion may be closed or more likely remain open when available energy is insufficient. Below a certain ratio, lesions will not be closed by tissue regeneration and energy loss will increase linearly with lesion perimeter. Damage in very small colonies is likely to leave too little tissue to supply enough energy for complete regeneration. Consequently, small colonies may have high mortality because they do not recover from damage.

Our data emphasise the importance of the ratio lesion size/lesion perimeter, which will determine whether a lesion will be closed or not. This ratio appears to be of general importance in the ecology of patches (Sousa 1984). The importance of patch shape (Paine \& Levin 1981) has not been assessed quantitatively in the recovery of space in coral reefs. The rate at which a patch is closed depends on the ratio of patch perimeter length / patch surface area in benthic communities (Sousa 1984). Small patches in mono-specific stands are closed by vegetative ingrowth from the perimeter. In larger patches growth from the perimeter is approximately the same and not enough to close the patch (Paine \& Levin 1981).

\section{Growth}

Removing the cores from the reef and measuring their growth did not affect calcification. This confirms Davies' (1989) results, which showed no difference between colonies measured daily, weekly, and every 3 wk.

Two undamaged cores of the same colony always showed very similar growth rates, but between colonies there was large variation (Fig. 4). Because we compared the average difference in growth between the 2 cores from the same colony, we corrected for the variation between colonies. Because the damaged and control group consisted of the same genetic material, growth patterns of these 2 groups are very similar through time (Fig. 6). Large, possibly inherent, intercolony variability has been reported before (Bak 1976, Barnes \& Crossland 1982, Dodge et al. 1984). The coefficient of variation in this study was $27 \%$, while others have reported values of $35 \%$ (Dodge et al. 1984) and $50 \%$ (Barnes \& Crossland 1982). This difference in coefficients may be caused by methodological differences or may be a species-specific characteristic.

Davies (1990) reports growth rates of Montastrea annularis of 1.9 to $1.1 \mathrm{mg} \mathrm{cm} \mathrm{cm}^{-2} \mathrm{~d}^{-1}$ (same depth as in this study), which are generally lower than ours (3.6 to $1.5 \mathrm{mg} \mathrm{cm}^{-2} \mathrm{~d}^{-1}$ ). This difference in growth might be due to generally higher water transparency in Curaçao. Using reported water transparency values (Tomascik \& Sander 1985) for the station where Davies found the highest growth, we calculated that the light extinction coefficient was about twice as high as that found normally in Curaçao (Bosscher \& Meesters 1992).

Growth increased linearly with the amount of irradiance (Fig. 2). This is not contradictory to the notion that the relation growth-irradiance follows a hyperbolic 
tangent curve (Chalker et al. 1988, Bosscher \& Meesters 1992) because we measured growth on a daily basis. During most of a normal day, PAR intensity is above $I_{0.95}$, the irradiance at which photosynthesis is $95 \%$ of the maximum photosynthesis (Barnes \& Chalker 1990). Therefore growth versus the daily increase in received radiation can be described by a straight line (Bak 1974, Gladfelter 1984).

However, growth decreased through time in our experiment, approaching the values found by Davies (1990). Handling (tested during 16 d) had no influence on growth, but other factors such as temperature (Clausen \& Roth 1975, Houck et al. 1977, Jokiel \& Coles 1977), sedimentation (Dodge et al. 1974, Bak 1978), eutrophication (Tomascik \& Sander 1985, Tomascik 1990), and availability of plankton (Lewis 1974, Wellington 1982) are known to affect calcification. The decreasing growth rate through time in our experiments is probably caused by temperature. We found a significant inverse relationship between temperature (measured with a calibrated electronic thermometer) and growth (Spearman correlation coefficient $r_{\mathrm{S}}=-0.65, \mathrm{p}=0.022 ;$ Fig. 8). Daily radiation was rather constant during the period of this study, and all growth data were standardised to a normal day. We show that light was the main factor influencing growth but superimposed was another pattern that is correlated with temperature. Gladfelter (1984) also found decreasing growth with increasing ambient temperatures. Growth of Pacific corals at temperatures close to our study (Clausen \& Roth 1975; their temperature T 4) also decreased at a shift from 26 to $27^{\circ} \mathrm{C}$.

We conclude that regeneration is an important process in coral ecology. It results in an energy drain for the tissue bordering damaged areas and, consequently, a decrease in the chance of long-time survival of the colony as a whole.

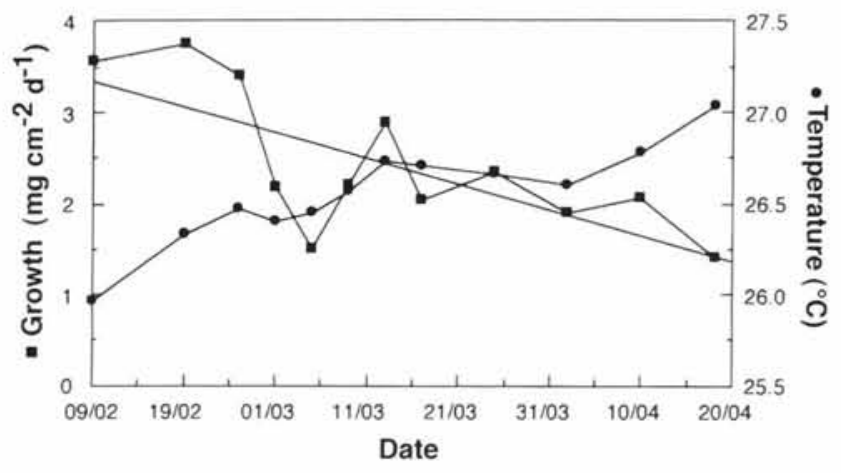

Fig. 8. Montastrea annularis. Increase in temperature (•) and decrease in the mean growth of cores without a lesion ( from February to April. Straight line is calculated regression line (Table 4)
Acknowledgements. Werner Pauchli's marine and terrestrial support is gratefully acknowledged. We thank the Carmabi Institute for providing logistic support, and O. Frans, F. Isabella and $\mathrm{A}$. Thiel for diving and other assistance in the field. This research was supported by a grant from the Netherlands Foundation for the Advancement of Tropical Research (WOTRO) W84-311.

\section{LITERATURE CITED}

Babcock, R. C. (1991). Comparative demography of three species of scleractinian corals using age- and size-dependent classifications. Ecol. Monogr. 61: 225-244

Babcock, R., Davies, P. (1991). Effects of sedimentation on settlement of Acropora millepora. Coral Reefs 9: 205-208

Bak, R. P. M. (1973). Coral weight increment in situ. A new method to determine coral growth. Mar. Biol. 20: 45-49

Bak, R. P. M. (1974). Available light and other factors influencing growth of stony corals through the year in Curaçao. Proc. 2nd int. Symp. coral Reef 2: 229-233

Bak, R. P. M. (1976). The growth of coral colonies and the importance of crustose coralline algae and burrowing sponges in relation with carbonate accumulation. Neth. J. Sea Res. 10: 285-337

Bak, R. P. M. (1978). Lethal and sublethal effects of dredging on reef corals. Mar. Pollut. Bull. 9: 14-16

Bak, R. P. M. (1983). Neoplasia, regeneration and growth in the reef-building coral Acropora palmata. Mar. Biol. 77; 221-227

Bak, R. P. M., Brouns, J. J. W. M., Heys, F. M. L. (1977). Regeneration and aspects of spatial competition in the Scleractinian corals Agaricia agaricites and Montastrea annularis. Proc. 3rd int. Symp. coral Reef 1: 143-149

Bak, R. P. M., Criens, S. R. (1981). Survival after fragmentation of colonies of Madracis mirabilis, Acropora palmata and $A$. cervicornis (Scleractinia) and the subsequent impact of a coral disease. Proc. 4 th int. Symp. coral Reef 2 : 221-227

Bak, R. P. M., Elgershuizen, H. B. W. (1976). Patterns of oilsediment rejection in corals. Mar. Biol. 37: 105-113

Bak, R. P. M., Eys, G. v. (1975). Predation of the sea urchin Diadema antillarum Philippi on living coral. Oecologia 20: $111-115$

Bak, R. P. M., Steward-van Es, Y. (1980). Regeneration of superficial damage in the scleractinian corals Agaricia agaricites f. purpurea and Porites astreoides. Bull. mar. Sci. 30: 883-887

Barnes, D. J., Chalker, B. E. (1990). Calcification and photosynthesis in reef-building corals and algae. In: Dubinsky, Z. (ed.) Ecosystems of the world. Elsevier, Amsterdam, p. $109-131$

Barnes, D. J., Crossland, C. J. (1982). Variability in the calcification rate of Acropora acuminata measured with radioisotopes. Coral Reefs 1: 53-57

Bertalanffy, L. v. (1957). Quantitative laws in metabolism and growth. Quant. Rev. Biol. 32: 217-231

Bosscher, H., Meesters, E. H. (1992). Depth related changes in the growth of Montastrea annularis. Proc, 7th int. coral Reef Symp. (in press)

Brown, B. E., Howard, L. S. (1985). Assessing the effects of 'stress' on reef corals. Adv. mar. Biol. 22: 1-63

Cameron, A. M., Endean, R., DeVantier, L. M. (1991). The effects of Acanthaster planci predation on populations of two species of massive coral. Hydrobiologia 216/217: 257-262

Chalker, B. E., Barnes, D. J., Dunlap, W. C., Jokiel, P. L. 
(1988). Light and reef-building corals. Interdis. Sci. Rev. 13: $222-237$

Clausen, C. D., Roth, A. A. (1975). Effect of temperature and temperature adaptation on calcification in the hermatypic coral Pocillopora damicornis. Mar. Biol. 33: 93-100

Cortes, N. J., Risk, M. J. (1985). A reef under siltation stress, Cahuita, Costa Rica. Bull. mar. Sci. 36:339-356

Davies, P. S. (1989). Short-term growth measurements of corals using an accurate buoyant weighing technique. Mar. Biol. 101: 389-395

Davies, P. S. (1990). A rapid method for assessing growth rates of corals in relation to water pollution. Mar. Pollut. Bull. 21 $346-348$

Davies, P. S. (1991). Effect of daylight variations on the energy budgets of shallow-water corals. Mar. Biol. 108: 137-144

Dodge, R. E., Aller, R., Thomson, J. (1974). Coral growth related to resuspension of bottom sediments. Nature 247: 574-577

Dodge, R. E., Wyers, S. C., Frith, H. R., Knap, A. H., Smith, S. R., Cook, C. B., Sleeter, T. D. (1984). Coral calcification rates by the buoyant weight technique: effects of alizarin staining. J. exp. mar. Biol. Ecol. 75: 217-232

Endean, R. (1973). Destruction and recovery of coral reef communities. In: Jones, O. A., Endean, R. (eds.) Biology and geology of coral reefs. Academic Press, London, p. 271-324

Fishelson, L. (1973). Ecological and biological phenomena influencing coral-species composition on the reef tables at Eilat (Gulf of Aquaba, Red Sea). Mar. Biol. 19: 183-196

Franzisket, L. (1964). Die Stoffwechselintensität der Riffkorallen und ihre ökologische, phylogenetische und soziologische Bedeutung. Z. vergl. Physiol. 49: 91-113

Gladfelter, E. H. (1984). Skeletal development in Acropora cervicornis. III. A comparison of monthly rates of linear extension and calcium carbonate accretion measured over a year. Coral Reefs 3: 51-57

Goreau, T. F. (1959). The physiology of skeleton formation in corals. I. A method for measuring the rate of calcium deposition by corals under different conditions. Biol. Bull. 116 $59-75$

Goreau, T. F. (1963). Calcium carbonate deposition by coralline algae and corals in relation to their role as reefbuilders. Ann. N.Y. Acad. Sci. 109: 127-167

Houck, J. E., Buddemeier, R. W., Smith, S. V., Jokiel, P. L. (1977). The response of coral growth rate and skeletal strontium content to light intensity and water temperature. Proc. 3rd int. coral Reef Symp. 2: 425-431

Hudson, J. H. (1981). Response of Montastrea annularis to environmental change in the Florida Keys. Proc. 4th int. coral Reef Symp. 2: 233-240

Hunte, W., Wittenberg, M. (1992). Effects of eutrophication and sedimentation on juvenile corals. 2. Settlement. Mar. Biol. 114: 625-631

Jackson, J. B. C., Coates, A. G. (1986). Life cycles and evolution of clonal (modular) animals. Phil. Trans. R. Soc. Lond B 313: 7-22

Jokiel, P. L., Coles, S. L. (1977), Effects of temperature on the mortality and growth of Hawaian reef corals. Mar. Biol. 43 201-208

Jokiel, P. L., Coles, S. L. (1990). Response of Hawaiian and other Indo-Pacific reef corals to elevated temperature. Coral Reefs 8: 155-162

Jokiel, P. L., Maragos, J. E., Franzisket, L. (1978). Cora growth: buoyant weight technique. Monogr. oceanogr. Methodol. (UNESCO) 5: 529-542

Kawaguti, S., Sukamoto, D. (1948). The effect of light on the calcium depostion of corals. Bull, Oceanogr. Inst. Taiwan
4: $65-70$

Kendall, J. J., Powell, E. N., Connor, S. J., Bright, T. J. (1983). The effects of drilling fluids (muds) and turbidity on the growth and metabolic state of the coral Acropora cervicornis, with comments on methods of normalisation for coral data. Bull. mar. Sci. 33: 336-352

Lang, J. C., Chornesky, E. A. (1990). Competition between scleractinian reef corals - a review of mechanisms and effects. In: Dubinsky, Z. (ed.) Ecosystems of the world 25 . Coral reefs. Elsevier, Amsterdam, p. 209-252

Lester, R. T., Bak, R. P. M. (1985). Effect of environment on regeneration of tissue lesions in the reef coral Montastrea annularis (Scleractinia). Mar. Ecol. Prog. Ser. 24: 183-185

Lewis, J. B. (1974). The importance of light and food upon the early growth of the reef coral Favia fragum. J. exp. mar. Biol. Ecol. 15: 299-304

Loya, Y. (1972). Community structure and species diversity of hermatypic corals at Eilat, Red Sea. Mar. Biol. 13: 100-123

Loya, Y. (1976). Skeletal regeneration in a Red Sea scleractinian coral population. Nature 261: 490-491

Meesters, E. H., Bak, R. P. M. (1993). Effects of coral bleaching on tissue regeneration and colony survival. Mar. Ecol. Prog. Ser. 96: 189-198

Meesters, E. H., Bos, A., Gast, G. J. (1992). Effects of sedimentation and lesion position on coral tissue regeneration. Proc. 7th int. coral Reef Symp. (in press)

Neudecker, S. (1981). Growth and survival of scleractinian corals exposed to thermal effluents at Guam. Proc. 4 th int. coral Reef Symp. 1: 173-180

Ott, B., Lewis, J. B. (1972). The importance of the gastropod Coralliophila abbreviata (Lamarck) and the polychaete Hermodice carunculata (Pallas) as coral reef predators. Can. J. Zool. 50: 1651-1656

Paine, R. T. Levin, S. A. (1981). Intertidal landscapes: disturbance and the dynamics of pattern. Ecol. Monogr. 51: $145-178$

Rinkevich, B., Loya, Y. (1989). Reproduction in regenerating colonies of the coral Stylophora pilstillata. In: Spanier, E., Steinberger, Y., Luria, M. (eds.) Environmental quality and ecosystem stability. Hebrew University, Jerusalem, p. $257-265$

Rogers, C. S. (1990). Responses of coral reefs and reef organisms to sedimentation. Mar. Ecol. Prog. Ser. 62: 185-202

Rogers, C. S. (1993). Hurricanes and coral reefs: the intermediate disturbance hypothesis revisisted. Coral Reefs 12: $127-137$

Sokal, R. R., Rohlf, F. J. (1981). Biometry, 2nd edn. W. H. Freeman and Company, New York

Sousa, W. P. (1984). The role of disturbance in natural communities. A. Rev. Ecol. Syst. 15: 353-391

Tomascik, T. (1990). Growth rates of 2 morphotypes of Montastrea annularis along a eutrophication gradient, Barbados, W.I. Mar. Pollut. Bull. 21: 376-381

Tomascik, T. (1991). Settlement patterns of Caribbean scleractinian corals on artificial substrata along a eutrophication gradient, Barbados, West Indies. Mar. Ecol. Prog. Ser. 77: 261-269

Tomascik, T., Sander, F. (1985). Effects of eutrophication on reef-building corals. I. Growth rate of the reef-building coral Montastrea annularis. Mar. Biol. 87: 143-155

Tomascik, T., Sander, F. (1987a). Effects of eutrophication on reef-building corals. II. Structure of scleractinian coral communities on fringing reefs, Barbados, West Indies. Mar. Biol. 94: 53-75

Tomascik, T., Sander, F. (1987b). Effects of eutrophication on reef-building corals. III. Reproduction of the reef-building coral Porites porites. Mar. Biol. 94: 77-94 
Van Veghel, M. L. J., Bak, R. P. M. (1993). Intraspecific variation of a dominant Caribbean reef building coral, Montastrea annularis: genetic, behavioral and morphometric aspects. Mar. Ecol. Prog. Ser. 92: 255-265

Wellington, G. M. (1982). An experimental analysis of the effects of light and zooplankton on coral zonation. Oecologia $52: 311-320$

This article was submitted to the editor
Wilkinson, L. (1989). Systat: the system for statistics. Systat, Inc., Evanston, IL

Wittenberg, M., Hunte, W. (1992). Effects of eutrophication and sedimentation on juvenile corals. Mar. Biol. 112: $131-138$

Zar, H. Z. (1984). Biostatistical analysis, 2nd edn. PrenticeHall, Inc., Englewood Cliffs, NJ

Manuscript first received: December 16, 1993 Revised version accepted: June 7, 1994 